\title{
PENINGKATAN PENDAPATAN MELALUI PENDAMPINGAN PENGEMBANGAN USAHA MIKRO EMPING MELINJO DIKELURAHAN KANDANG KOTA BENGKULU
}

\section{INCOME IMPROVEMENT THROUGH MICRO SCALE-ENTERPRISE DEVELOPMENT MENTORING GNETUM CHIPS IN KELURAHAN KANDANG BENGKULU CITY}

\author{
Oleh: \\ Dri Asmawanti $S^{l}$, Heni Nopianti ${ }^{2}$, Afdhal Kurniawan Mainil ${ }^{3}$ \\ ${ }^{1}$ Fakultas Ekonomi dan Bisnis Universitas Bengkulu \\ ${ }^{2}$ Fakultas Ilmu Sosial dan Ilmu Politik Universitas Bengkulu \\ ${ }^{3}$ Fakultas Teknik Universitas Bengkulu \\ driasmawantis@unib.ac.id
}

\begin{abstract}
This community service activitiy aims to improve the capacity, knowledge and skills in various aspects of micro scale enterprise (MSE) or business of gnetum chips (production, management and law). In addition, the goal is improving the quantity and quality of produced gnetum chips. The training has been done to diversify the products processed chips gnetum IE cookies crackers and chips caramelized on the Group micro scale business of Rafflesia and Cempaka in Bengkulu City. In management aspects of the business, it has been implemented various activities that can enhance the knowledge and skills of the partners in managing their business, such as business management and computerized marketing training. Lastly, in terms of the law, it has been implemented mentoring of legal permission to partner in order to register their business to P-IRT.
\end{abstract}

Keywords: mikro scale enterprise, genum (emping), business, income

\section{PENDAHULUAN}

Usaha kecil dan menengah (UKM) merupakah salah satu bagian terpenting dalam perekonomian Indonesia. UKM berperan penting dalam penyerapan tenaga kerja indonesia dan penurunan angka pengangguran, pemanfaatan bahan baku lokal, dan dengan UKM juga dapat menambah jumlah unit usaha baru yang mendukung peningkatan pendapatan rumah tangga warga masyarakat (Nuryanti, 2013).

Salah satu UMKM yang berkembang di Provinsi Bengkulu adalah di daerah Kelurahan kandang, secara geografis memiliki letak daerah yang berdekatan dengan kawasan pinggir pantai sehingga menjadikan daerah ini memiliki tanah yang subur. Salah satu perkebunan yang sangat berkembang di daerah ini adalah pohon melinjo, yang telah ditanam sejak tahun 1970an. Oleh karena itu, pohoh melinjo telah dimanfaatkan cukup lama oleh masyarkatnya sebagai lahan mata pencaharian dengan memanfaatkan biji melinjo. Namun, dalam beberapa tahun terakhir, warga sangat kesulitan mendapatkan buah 
melinjo yang banyak. Masyarakat mencoba mencari solusi keterbatasan bahan baku melinjo dengan memasok bahan baku dari Enggano, Bengkulu Utara. Ini dikarenakan masyarakat tidak dapat hanya mengandalkan atau bergantung pada bahan baku dari lahan mereka sendiri, harus ada pasokan tambahan dari daerah lain untuk mencukupi kebutuhan produksi emping melinjo. Dengan demikian tambahan pasokan melinjo ini akan menyebabkan biaya produksi meningkat dan harga jual emping melinjo semakin naik.

Untuk menambah penghasilan masyarakat yang tergabung dalam usaha kecil dan menengah emping melinjo ini adalah salah satunya dengan membuat diversifikasi produk olahan emping. Agar melinjo yang tersedia tidak hanya dibuat emping saja namun dapat diolah menjadi produk yang lebih menarik, mempunyai cita rasa yang berbeda dan menaikkan nilai ekonomi dari emping itu sendiri.

Selain itu mitra belum mampu melakukan pengelolaan usaha dengan baik. Hal itu terlihat dari pengelolaan keuangan usaha yang belum maksimal dan pemasaran yang masih sangat terbatas. Oleh karena itu diperlukan peningkatan kemampuan, pengetahuan dan keterampilan mitra dalam mengelola usahanya, baik dari segi pengelolaan/pencatatan keuangan maupun metode pemasaran yang digunakan oleh mitra. Dari aspek hukum, mitra belum pernah mendapatkan informasi terkait dengan perijinan usaha. Dengan demikian, diperlukan usaha pendampingan kepada mitra dalam memberikan pengetahuan perizinan usaha, sehingga produk yang dihasilkan oleh mitra akan segera mendapatkan izin usaha secara resmi, salah satunya adalah izin Pangan Industri Rumah Tangga (P-IRT).

\section{METODE PENGABDIAN}

Diversifikasi produk olahan emping yang diberikan kepada pengrajin usaha mikro mandiri di kelurahan Dusun Kandang.Tim pelaksana menlakukan simulasi atau demonstrasi bagaimana pembuatan varian produk yang berbahan baku emping, yaitu cookies emping dan emping caramel. Peserta kegiatan ikut serta membuat produk-produk tersebut dengan tujuan peserta dapat mempraktekkan resepnya secara kelompok pada tahapan selanjutnya.Peserta kegiatan sangat antusias mengikuti kegiatan ini, dikarenakan sebelumnya mitra belum pernah melakukan diversifikasi produk seperti ini, melainkan hanya menjual emping mentah saja.

Adapun cara pembuatan diversifikasi produk adalah sebagai berikut:

a. Cookies Emping

Bahan yang dibutuhkan:

115 g margarin

$25 \mathrm{~g}$ wisman/butter

100 g gula halus

1 btr kuning telur

1 sdm susu bubuk

$125 \mathrm{~g}$ tepung terigu protein sedang 
Keripik melinjo secukupnya

Manisan ceri secukupnya

Cara Membuat:

1. Kocok margarin, mentega dan gula halus hingga lembut

2. Tambahkan kuning telur dan susu bubuk, kocok rata

3. Masukkan tepung terigu, aduk rata

4. Ambil satu sendok teh adonan lalu gulingkan dalam keripik melinjo

5. Hiasi permukaannya dengan potongan manisan ceri

6. Letakkan di atas loyang datar

7. Panggang dengan suhu $140^{\circ} \mathrm{C}$ hingga matang. Angkat dan dinginkan.

b. Emping Karamel

Bahan:

250 g Keripik Melinjo

2 gelas gula pasir

$1 / 4$ gelas air

Cara Membuat:

1. Sangrai gula pasir hingga mencair

2. Setelah gula cair berbuih, masukkan air

3. Setelah agak dngin, masukkan keripik melinjo, aduk rata.

4. Dinginkan lalu angkat

Selain kegiatan diatas, tim pelaksana mengadakan kegiatan dalam aspek manajemen usaha. Kegiatan yang telah dilaksanakan dalam bentuk pelatihan manajemen usaha dan kegiatan pelatihan pemasaran berbasis komputer. Peserta dibekali materi tentang kewirausahaan, pencatatan keuangan/akuntansi untuk Usaha Kecil dan Menengah (UKM) serta pengetahuan tentang metode pemasaran yang efektif. Pada sesi materi kewirausahaan, tim pelaksana membangkitkan semangat wirausaha peserta agar berkeinginan meningkatkan pendapatan dan pengembangan usaha mereka.

Pada aspek pemasaran, tim pelaksana memberikan pengetahuan dan informasi kepada peserta dalam melakukan pemasaran yang baik. Salah satu aspek yang juga penting adalah penggunaan teknologi berbasis komputer atau internet untuk mengembangkan pemasaran produk dan melebarkan jaringan usaha di seluruh belahan dunia usaha, terlebih lagi akses internet semakin mudah dan murah untuk diperoleh (Nuryanti 2013). Pemasaran produk emping ini dapat mereka lakukan sendiri. Selain mereka dapat meletakkan produknya di etalase yang sudah ada, mereka juga dibekali bagaimana caranya untuk memasarkan produk lewat media online, seperti memasarkan produknya lewat toko online 
Bukalapak, Tokopedia, Shopee, dan lain-lain. Tim juga membantu peserta untuk membuat label pada kemasan dan mengganti plastik kemasan yang digunakan peserta.

Adapun alat yang telah diberikan kepada mitra adalah sebagai berikut:

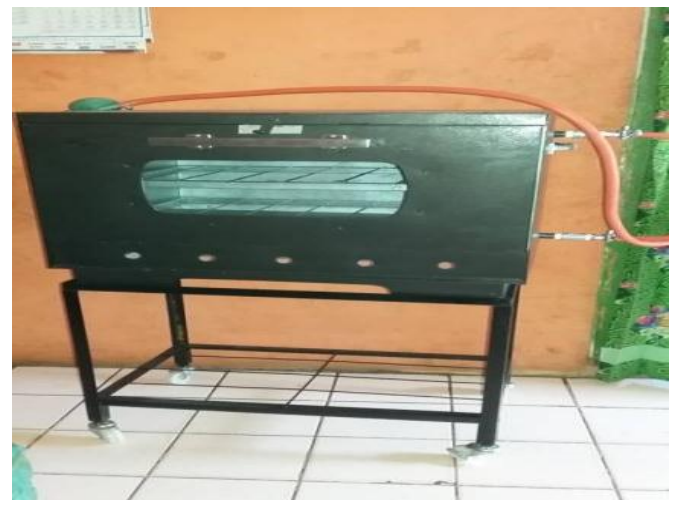

Gambar 1. Oven Gas

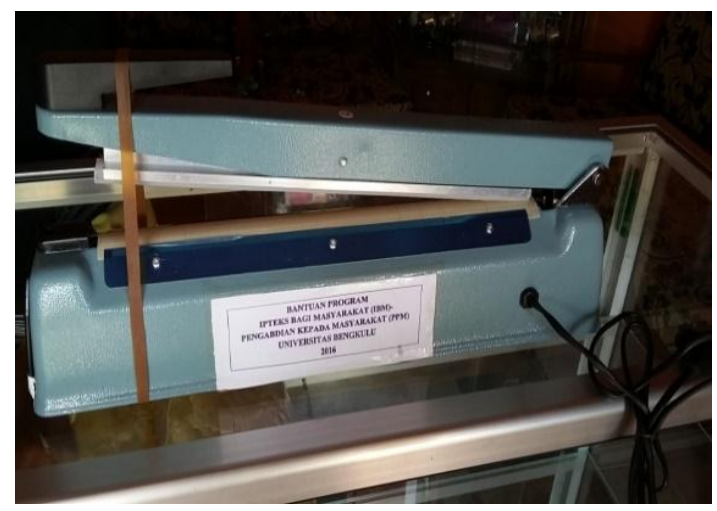

Gambar 2. Hand Sealer/Alat Press Kemasan

Dalam sudut pandang ekonomi aspek penerapan akuntansi dan berbagai inovasi dalam menghadapi persaingan dunia usah abaik dalam pengembangan strategi kompetitif bisnis (Robbins dan Coulter, 2010). Pada sesi pencatatan keuangan/akuntansi, tim pelaksana memberikan materi dasar bagaimana usaha para peserta dapat dilakukan pencatatan keuangan dengan baik, benar dan sederhana.Sehingga pencatatan keuangan tersebut, nantinya dapat dilaksanakan dan dapat dimengerti oleh semua peserta. Dengan demikian, peserta dapat mengetahui berapa keuntungan yang diperoleh usaha mereka dan dapat melakukan evaluasi terhadap perjalanan usaha peserta.

Ditinjau dari aspek hukum, rangkaian kegiatan yang telah dilaksanakan adalah dimulai dari kegiatan sosialisasi pentingnya izin usaha untuk legalitas produk yang dihasilkan peserta.Selanjutnya pendampingan usaha mitra untuk memperoleh izin usaha di Dinas Kesehatan Kota Bengkulu khususnya izin usaha Industri Pangan Rumah Tangga (PIRT). Adapun persyaratan yang harus dilengkapi untuk memperoleh izin usaha ini adalah sebagai berikut:

1. Formulir Permohonan Izin PIRT

2. Sertifikat PKP

3. Fotokopi KTP

4. Pas Foto ukuran $3 \times 4$ sebanyak 2 lembar

5. Surat Keterangan Usaha dari Kantor Lurah

6. Keterangan Sehat dari Dokter

7. Denah Lokasi Usaha

\section{HASIL DAN PEMBAHASAN}

Kegiatan pelatihan diversifikasi olahan emping melinjo di Kelurahan Dusun Kandang mendapatkan respon yang positif dari warga setempat. Para pengrajin usaha 
mikro yang tergabung dalam dua kelompok yaitu kelompok Raflesia dan Cempaka merasa sangat terbantukan dengan adanya kegiatan ini. Selama ini, mereka hanya mengolah melinjo untuk dibuat emping mentah saja, dan kemudian dijual. Selain melakukan pelatihan, mereka juga diberikan bantuan yang berupa alat penunjang untuk memproduksi olahan emping ini, antara lain oven gas dan wajan besi. Alat ini sangat bermanfaat bagi peserta khususnya dapat digunakan dalam pembuatan cookies emping, dimana peserta telah membuat cookies secara mandiri dengan anggota kelompoknya masing-masing. Hasil produk yang telah dibuat peserta, telah dipasarkan pada beberapa ajang pameran tingkat provinsi, yaitu Bengkulu Expo dan Unib (Universitas Bengkulu) Fair, dimana Bengkulu Expo dilaksanakan pada tanggal 17 November sampai tanggal 21 November 2016, sedangkan Bengkulu Expo telah dilaksanakan pada tanggal 23 dan 24 November 2016. Beberapa produk yang dipasarkan pada ajang tersebut sudah laku terjual dan produksi produk-produk tersebut dapat ditingkatkan lagi pada masa yang akan datang.

Untuk menunjang pelaksanaan kegiatan pemasaran, tim pelaksana memberikan bantuan alat berupa hand sealer/mesin press kemasan yang dapat digunakan untuk membungkus produk. Selain itu, tim pelaksana memberikan bantuan berupa etalase kaca sebagai tempat untuk memasarkan hasil produk mitra di toko peserta.

Selanjutnya pada aspek hukum, pendampingan mitra untuk memperoleh izin usaha telah dilakukan. Rangkaian kegiatan yang telah dilaksanakan adalah sebagai berikut:

1. Pendaftaran di Dinas Kesehatan Kota Bengkulu

2. Peserta mengikuti Pelatihan/Penyuluhan Keamanan Pangan

3. Peserta memperoleh sertifikat kegiatan pelatihan, dimana sertifikat dilampirkan sebagai salah satu persyaratan berikutnya

4. Melengkapi persyaratan lain yang dibutuhkan untuk mendaftarkan ke Badan Pelayanan Perizinan Terpadu (BPPTM)

5. Survey lokasi yang dilakukan oleh Tim survey dari BPPTM

Pada akhir kegiatan, Nomor izin industry sudah dapat diperoleh Mitra pengadian. Adapun Sertifikat Produksi Pangan Industri Rumah Tangga telah diperoleh mitra pengabdian, dengan No.P-IRT 2.06.1771.02.08.43.21 untuk produk Kukis Melinjo Raflesia, sedangkan No.P-IRT 2.14.1771.01.0843.21 untuk produk Emping Melinjo "Raflesia".

Selama kegiatan berlangsung, peserta sangat antusias untuk membuat diversifikasi produk ini, dikarenakan dapat secara langsung meningkatkan pendapatan usaha emping melinjo mereka.

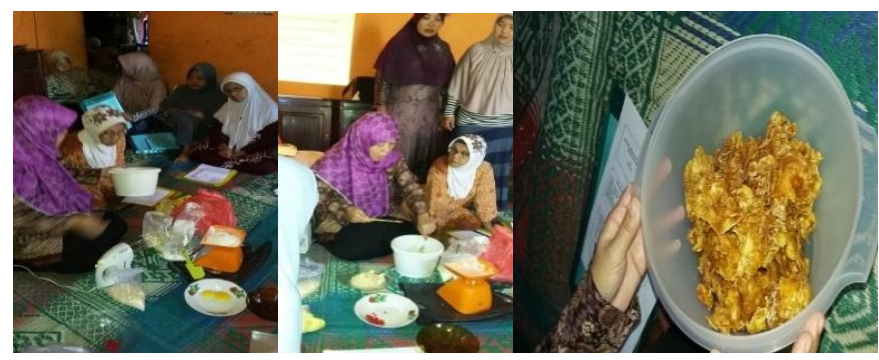


Gambar 1. Pembuatan Diversifikasi produk

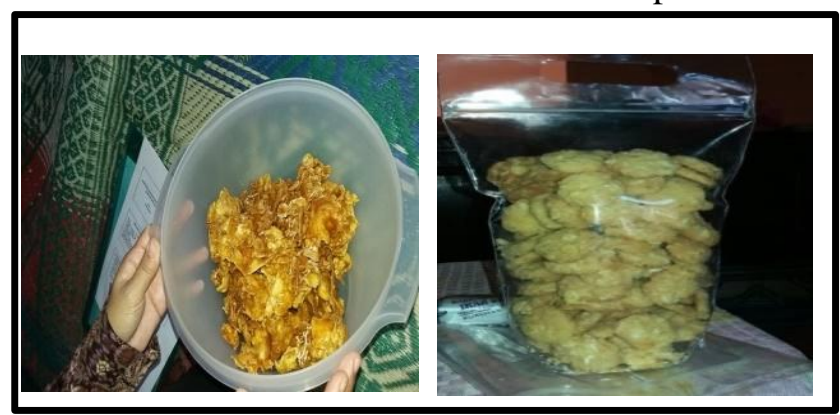

a

b

Gambar 2. Foto Produk olahan emping melinjo

(a) Melinjo Karamel (b) Cookies Melinjo

\section{KESIMPULAN}

1. Emping melinjo dapat diolah menjadi produk yang lebih bernilai ekonomi tinggi, antara lain cookies emping dan emping karamel. UKM Raflesia dan Cempaka merasa terbantukan dengan adanya kegiatan pelatihan diversifikasi produk, manajemen usaha dan pemasaran produk, sehingga wawasan mereka dapat meningkatkan pendapatan usaha dengan varian produk emping ini.

2. Mitra telah melakukan pemasaran yang baik dengan pengemasan yang menarik.

3. Mitra juga telah dibantu didampingi mendaftarkan hasil produk mereka untuk mendapatkan ijin usaha P-IRT.

\section{DAFTAR PUSTAKA}

Nuryanti, 2013, Peran E-Commerce untuk Meningkatkan Daya Saing Usaha Kecil dan Menengah (UKM), Jurnal Ekonomi, Vol. 21, No.4, Universitas Pendidikan Indonesia.

Robbins, S.P., M. Coulter, 2010, Manajemen, Edisi kesepuluh, Erlangga, Jakarta. 